\title{
Resistance to freshwater exposure in White Sea Littorina spp. Il: Acid-base regulation
}

Accepted: 23 December 1999

\begin{abstract}
Parameters of acid-base and energy status were studied by in vivo ${ }^{31} \mathrm{P}$-nuclear magnetic resonance spectroscopy in three White Sea Littorina spp. (L. littorea, L. saxatilis and L. obtusata) during prolonged anaerobiosis in freshwater. Intracellular $\mathrm{pH}$ decreased significantly, especially during the early period of anaerobiosis, but later the decrease in intracellular $\mathrm{pH}$ slowed down considerably, suggesting a capacity for intracellular $\mathrm{pH}$ regulation in all three species. There was a trend for intracellular $\mathrm{pH}$ to fall most rapidly in the least freshwater-resistant species, L. obtusata, as compared to the most resistant, L. littorea. Non-bicarbonate, non-phosphate buffer values estimated by the homogenate technique were similar in the three studied species (28-37 mmol pH $\mathrm{pg}^{-1} \mathrm{~kg}^{-1}$ wet weight) and did not change during freshwater exposure. The $\mathrm{CaCO}_{3}$ buffer value of the foot tissues was considerably higher (171$218 \mathrm{mmol} \mathrm{pH}^{-1} \mathrm{~kg}^{-1}$ wet weight) and decreased significantly during freshwater exposure. The contribution of the multiple tissue buffering systems to intracellular $\mathrm{pH}$ regulation in Littorina spp. shifts between different stages of freshwater exposure. Initially, the non-bicarbonate, non-phosphate tissue buffering system seems to be of major importance for metabolic proton buffering
\end{abstract}

Communicated by G. Heldmaier

I. M. Sokolova $(\bowtie)^{1}$

White Sea Biological Station,

Zoological Institute of the Russian Academy of Sciences,

Universitetskaya nab., 1, 199034 St. Petersburg, Russia

C. Bock · H.-O. Pörtner

Alfred-Wegener-Institute for Polar and Marine Research, Ecophysiology and Ecotoxicology, Columbusstr., 30,

D-27568, Bremerhaven, Germany

Present address:

${ }^{1}$ Alfred-Wegener-Institute for Polar and Marine Research, Ecophysiology and Ecotoxicology, Columbusstr., 30,

D-27568, Bremerhaven, Germany

e-mail: ISokolova@awi-bremerhaven.de

Tel.: +49-471-48311-311; Fax: + 49-471-48311-149 at intracellular $\mathrm{pH}$ between 7.5 and 7.0. During later stages of anaerobiosis and at lower intracellular $\mathrm{pH}$, the $\mathrm{CaCO}_{3}$ buffer is involved in proton buffering. Decrease in the $\mathrm{CaCO}_{3}$ buffer value during freshwater exposure was in quantitative agreement with the amount of metabolic protons buffered, thus suggesting that $\mathrm{CaCO}_{3}$ tissue stores may serve as a major buffering system during prolonged anaerobiosis in Littorina spp.

Key words Salinity stress - Anaerobiosis . Intracellular $\mathrm{pH}$ - Tissue buffer values ${ }^{31} \mathrm{P}-\mathrm{NMR}$

Abbreviations $A N O V A$ analysis of variance $\cdot A T P$ adenosine- $5^{\prime}$-triphosphate $\cdot F$ fraction of protonated phosphate $\cdot N M R$ nuclear magnetic resonance $\cdot N T A$ nitrilotriacetic acid $\cdot \mathrm{PCO}_{2}$ partial pressure of $\mathrm{CO}_{2} \cdot P D$ phosphodiesthers $\cdot p H_{i}$ intracellular $\mathrm{pH} \cdot P_{i}$ inorganic phosphorus $\cdot p K a$ apparent dissociation constant $\cdot P L A$ phospho-L-arginine $\cdot S / N$ ratio signal-to-noise ratio $\cdot W_{\text {tiss }}$ tissue wet weight $\cdot \beta_{\mathrm{CaCO}_{3}}$ calcium carbonate tissue buffer value $\cdot \beta_{H}$ non-bicarbonate buffer value of tissue homogenate $\cdot \beta_{N B, N P i}$ nonbicarbonate, non-phosphate tissue buffer value $\cdot \beta_{\mathrm{Pi}}$ inorganic phosphate tissue buffer value $\cdot \Delta H^{+}{ }_{\text {non-resp }}$ non-respiratory proton change $\cdot \Delta H^{+}{ }_{m e t}$ metabolic proton change $\cdot \Delta p H$ change of $\mathrm{pH} \cdot \Delta p H_{o b s}$ observed change of $\mathrm{pH}$

\section{Introduction}

Many intertidal animals, including gastropods, possess an outstanding ability to withstand and successfully adapt to a wide range of salinity fluctuations. If salinity changes strongly and rapidly, a very typical adaptive behavioural response is evoked in intertidal gastropods. Snails withdraw into the shell and isolate themselves inside by closing the operculum. Isolation minimises the exchange of water and salts between the internal medium of the animal and the osmotically unfavourable environment (e.g. Berger 1986). However, many physio- 
logically important functions like excretion, feeding, and reproduction are suspended during this period. In addition, animals remain practically anoxic during such isolation periods, explaining why this adaptive behavioural response results in only limited survival of the snails (Sokolova et al. 2000).

Prosobranch gastropods Littorina littorea, L. saxatilis and L. obtusata are common inhabitants of the White Sea intertidal zone. All three species are known to exhibit a fairly high resistance to extreme hypoosmotic stress and may survive from several days to more than a week in freshwater depending on environmental temperature (Berger 1986; Sokolova et al. 2000). This ability may be adaptive during the periods of spring ice-melting in the White Sea when the salinity of the surface water drops to $<2 \%$ in near-coastal areas for about 2 weeks (Babkov and Lukanin 1985). However, significant differences exist between the three Littorina spp. with respect to freshwater resistance. The low-shore periwinkle L. obtusata is most vulnerable to extreme hypoosmotic stress, whereas the resistance of the highshore L. saxatilis, and especially that of the subtidal species L. littorea is considerably higher. Our companion study (Sokolova et al. 2000) clearly demonstrated for the first time that exposure to an extremely hypoosmotic medium evokes anaerobic metabolism in the periwinkles evidenced by a large degree of succinate accumulation. Inability of anaerobic energy production to keep pace with energy demand leads to an impaired energy status of the tissue, reflected in a depletion of phosphagen stores and ATP levels, resulting in a reduction in the Gibbs free energy of ATP hydrolysis. Our data suggested that differential survival of the periwinkles under conditions of extreme hypoosmotic stress depends on their capacity to delay adverse changes in the energy status, which in turn is crucially related to the efficiency of metabolic rate depression and the ability to reduce ATP turnover during environmental anaerobiosis.

Besides the depression of metabolic and ATP turnover rates, other mechanisms, which can potentially contribute to anoxia resistance of the periwinkles, should not be neglected. Among them, the mechanisms of acid-base regulation preventing extreme acidification of the intracellular milieu during prolonged anaerobiosis are of primary importance. A decrease of intracellular $\mathrm{pH}\left(\mathrm{pH}_{\mathrm{i}}\right)$ may have adverse effects on enzyme functions and intracellular energy transductions (Pörtner 1987a, 1993). Although an extreme drop in $\mathrm{pH}_{\mathrm{i}}$ would have deleterious effect on cellular functions, a moderate decrease may be advantageous during anoxia, providing a necessary background for slowing down enzymatic reactions and for improving protein stability, hence contributing to metabolic arrest (Juretschke and Kamp 1990; Kamp 1993; Pörtner 1993; Hand and Hardewig 1996; Schmidt and Kamp 1996).

To obtain a more complete picture of the mechanisms of freshwater and anoxia resistance, changes in the parameters of acid-base status were analysed by in vivo
${ }^{31} \mathrm{P}$-nuclear magnetic resonance $\left({ }^{31} \mathrm{P}\right.$-NMR) and tissues homogenate techniques in White Sea gastropods L. littorea, L. saxatilis and L. obtusata. Changes in acidbase parameters were compared to anaerobic metabolic rates and mortality of the Littorina spp. studied in order to test whether the capacity for acid-base regulation contributes to differential survival of the snails under conditions of prolonged anoxia during extreme hypoosmotic stress. This approach also provides insight into the importance of acid-base parameters in metabolic regulation and vice versa. The buffer capacities of the multiple tissue buffering systems (non-bicarbonate, non-phosphate, inorganic phosphate and calcium carbonate) were compared in order to estimate the relative contribution of these systems to $\mathrm{pH}_{\mathrm{i}}$ regulation at different stages of environmental anaerobiosis in Littorina spp.

\section{Materials and methods}

\section{Sampling of Littorina spp.}

Sampling for determination of tissue buffer capacities was performed in August 1997 in the Chupa Inlet of the Kandalaksha Bay of the White Sea $\left(66^{\circ} 20^{\prime} \mathrm{N}, 33^{\circ} 40^{\prime} \mathrm{E}\right)$ at a water temperature of 10 $15{ }^{\circ} \mathrm{C}$ and $25-27 \%$ salinity. Details of the sampling procedure and the maintenance of the animals were as described elsewhere (Sokolova et al. 2000). Only adult snails with shell diameters of $7-$ $11 \mathrm{~mm}$ (L. saxatilis and L. obtusata) or 22-26 mm (L. littorea) were used in the experiments.

For ${ }^{31}$ P-NMR studies, adult Littorina were collected in October 1997 at the same sites (water temperature $5-7{ }^{\circ} \mathrm{C}, 26-27 \%$ salinity) and transported to the Alfred-Wegener Institute for Marine and Polar Research (Bremerhaven, Germany). Transportation took 2.5 days and all snails arrived alive. In the Alfred-Wegener Institute, snails were placed in a recirculating aquarium with natural North Sea water diluted with tap water to obtain a salinity of $26 \%$. Water temperature was maintained at $7.0-7.5^{\circ} \mathrm{C}$. Under these conditions snails were kept without feeding for 11 days prior to experimentation. Shell diameter of the periwinkles used in ${ }^{31} \mathrm{P}$ NMR studies was 8-12 mm for L. saxatilis and L. obtusata and 15$27 \mathrm{~mm}$ for L. littorea.

\section{Incubation procedure}

Experimental incubation and tissue sampling for determination of tissue buffer capacities (August 1997) were performed at the White Sea Biological Station (Cape Kartesh, White Sea). Temperature of incubation was $7.7 \pm 0.6{ }^{\circ} \mathrm{C}$. Control animals were kept in aquaria with aerated natural seawater of $26-27 \%$. Experimental animals were placed in plastic trays and covered with natural freshwater from the nearby Krivoye Lake. The water was changed daily. After specified exposure periods a portion of snails was taken out of the tray. Scoring for mortality and tissue sampling were performed as described elsewhere (Sokolova et al. 2000). Deep-frozen tissues were transported at liquid $\mathrm{N}_{2}$ temperature to the Alfred-Wegener Institute where all analyses were performed.

For ${ }^{31} \mathrm{P}-\mathrm{NMR}$ studies the periwinkles were placed in separate 200-ml plastic bottles covered only with cotton mesh. Each sample consisted of 7 or 8 individuals ( $L$. littorea) or 70-75 individuals $(L$. saxatilis and L. obtusata). Bottles were submerged into well-aerated aquaria with $26 \%$ seawater at $7.0-7.5^{\circ} \mathrm{C}$ and left overnight in order to reduce the effect of handling. For the measurements the bottles were removed and filled with $80 \mathrm{ml}$ of $26 \%$ seawater at the same temperature. The cotton mesh was gently replaced by a plastic grid to prevent movement of the snails during the NMR measurements. 
After analysis of control values the bottles were drained, the plastic grid removed and the bottles refilled with fresh tapwater, covered with cotton mesh and fixed in the aquarium with recirculating aerated freshwater at $7.0-7.1^{\circ} \mathrm{C}$. After specified exposure periods, samples were taken out of the aquarium, drained and checked for the presence of dead snails. To reduce the effect of handling, poking by a needle was not applied (see Sokolova et al. 2000) and only those snails that failed to keep the operculum tightly closed were scored as dead. The final scoring after the experiment revealed that the error of this mortality estimate was below $2 \%$ for $L$. saxatilis and $L$. obtusata and was $0 \%$ for $L$. littorea. Dead periwinkles were discarded. The NMR measurements in freshwater-exposed animals were performed under $80 \mathrm{ml}$ of freshwater. The whole procedure was repeated after every incubation period.

For each species, five samples were measured repeatedly as controls and at different exposure periods $(3,5$ days of freshwater exposure for $L$. obtusata and 3 days, 5 days and 7 days for $L$. saxatilis and L. littorea). For L. littorea, ${ }^{31} \mathrm{P}-\mathrm{NMR}$ spectra were obtained for five independent additional samples after 7 days and 9 days of freshwater exposure.

\section{${ }^{31} \mathrm{P}-\mathrm{NMR}$ measurements}

For in vivo ${ }^{31} \mathrm{P}-\mathrm{NMR}$ measurements the bottles were fixed onto a 5.0-cm-diameter ${ }^{1} \mathrm{H} /{ }^{31} \mathrm{P} /{ }^{13} \mathrm{C}$ surface coil and placed inside the magnet. The temperature was balanced via the water cooled gradient coil of the magnet $\left(8^{\circ} \mathrm{C}\right)$. All experiments were performed at $81 \mathrm{MHz}$ using a 47/40 Bruker Biospec DBX system with actively shielded gradient coils. In vivo ${ }^{31} \mathrm{P}-\mathrm{NMR}$ spectra were recorded with a sweep width of $4000 \mathrm{~Hz}, 60^{\circ} \mathrm{bp}$-pulses of $50 \mu$ s and a repetition time of $1 \mathrm{~s}$ for 600 scans resulting in an acquisition period of $10 \mathrm{~min}$ and a total measurement period of 20-30 min. All data were zero filled to $16 \mathrm{~K}$ and a line-broadening of $20 \mathrm{~Hz}$ was applied before Fourier transformation. Chemical shift values were expressed relative to phospho-L-arginine (PLA).

Mean $\mathrm{pH}_{\mathrm{i}}$ of the whole animal was determined by the chemical shift of the inorganic phosphorus $\left(\mathrm{P}_{\mathrm{i}}\right)$ signal in the NMR spectra and calculated with a formula of a $\mathrm{pH}$ titration curve from muscle fibres of the horseshoe crab Limulus polyphemus (Doumen and Ellington 1992) and corrected for temperature according to Pörtner (1990). Intracellular free magnesium concentrations were also determined from ${ }^{31} \mathrm{P}-\mathrm{NMR}$ spectra as described by Doumen and Ellington (1992). We assume that both $\mathrm{pH}$ and free magnesium concentration reflect intracellular values of these parameters because the $\mathrm{P}_{\mathrm{i}}$ concentration in haemolymph of marine gastropods is too low to become visible in NMR spectra (Kinne 1971; Berger 1986).

Integration of phosphorus compounds in the NMR spectra were obtained with the standard integration routine of the processing software (xwin-nmr, Bruker, Ettlingen). The typical line width of phosphorus signals was less than $40 \mathrm{~Hz}$ in control animals as well as in the spectra obtained under hypoosmotic stress conditions.

\section{Determination of tissue buffer capacity}

Tissue buffer capacity was determined in vitro by a method following the rationale of Pörtner (1990). Tissue samples were ground under liquid $\mathrm{N}_{2}$. Frozen tissue powder $(1-2 \mathrm{~g})$ of were placed into a preweighed tonometer vessel precooled on ice. To obtain this amount of tissue powder, foot muscles from 3 (L. littorea) or 28-30 (L. saxatilis and L. obtusata) individuals were pooled. Four millilitres of ice cold medium consisting of $0.54 \mathrm{~mol}^{-1} \mathrm{KF}$ and $0.01 \mathrm{~mol} \mathrm{l}^{-1}$ nitrilotriacetic acid (NTA) were added for each gram of tissue powder. The mixture was thoroughly stirred and allowed to thaw.

The tissue homogenate was placed into a tonometer (Instrumentation Laboratory, Padorno Dugano, Italy) and equilibrated for 20-30 min with normoxic humidified gas mixture at a partial pressure of $\mathrm{CO}_{2}\left(\mathrm{PCO}_{2}\right)$ of 3.6 torr provided by a gas mixing pump (Wösthoff, Bochum, Germany) at $8{ }^{\circ} \mathrm{C}$. Homogenate $\mathrm{pH}$ was continuously monitored using a fluoride-resistant $\mathrm{pH}$ electrode GAT IJ 42 (Gamma Analysentechnik, Bremerhaven, Germany) calibrated with WTW (Weilheim, Germany) precision buffers. The initial homogenate $\mathrm{pH}$ ranged between 8.4 and 8.6 and was considerably higher than the $\mathrm{pH}_{\mathrm{i}}$ measured in vivo by ${ }^{31} \mathrm{P}-\mathrm{NMR}$ probably due to the presence of calcium carbonate stores in the foot of the periwinkles (Mason et al. 1984; Brough and White 1990). Therefore, the homogenate was titrated back to approximately the respective average $\mathrm{pH}_{\mathrm{i}}$ values determined by ${ }^{31} \mathrm{P}-\mathrm{NMR}$ (see below) using $3 \mathrm{~mol} \mathrm{l}^{-1} \mathrm{HCl}$. During titration, the homogenate was equilibrated with a normoxic gas mixture at $\mathrm{PCO}_{2}=3.6$ torr. After $\mathrm{HCl}$ titration intracellular buffer value was determined using the $\mathrm{CO}_{2}$ titration method as described by Pörtner (1990). Normoxic gas mixtures with three partial pressures of $\mathrm{CO}_{2}$ were used: low ( 0.75 torr), medium (3.62 torr) and high ( 7.6 torr). At the end of experimentation, aliquots of the homogenate were withdrawn and subjected to ultrafiltration at 0 $4{ }^{\circ} \mathrm{C}$ using Millipore (Bedford, USA) Ultrafree PF units (30 000 d) for $50 \mathrm{~min}$. PCA extracts of the ultrafiltrates were prepared, and inorganic phosphate concentration was determined enzymatically (Pörtner 1990).

Calculations of non-bicarbonate buffer values in the tissue homogenate $\left(\beta_{\mathrm{H}}\right)$ followed the procedure outlined by Heisler and Piiper (1971):

$\beta_{\mathrm{H}}=\frac{0.5 \times\left(\mathrm{Bic}_{1}+\mathrm{Bic}_{3}\right)-\mathrm{Bic}_{2}}{0.5 \times\left(\mathrm{pH}_{1}+\mathrm{pH}_{3}\right)-\mathrm{pH}_{2}}\left(\mathrm{mmol} \mathrm{pH} \mathrm{pH}^{-1} \mathrm{l}^{-1}\right.$ homogenate water $)$

where indices 1 and 3 refer to values at medium $\mathrm{PCO}_{2}$, and index 2 to values at high or low $\mathrm{PCO}_{2}$. In order to evaluate the non-bicarbonate, non-phosphate buffer value $\left(\beta_{\mathrm{NB}, \mathrm{NPi}}\right)$ of the homogenate, the buffer value of inorganic phosphate $\left(\beta_{\mathrm{Pi}}\right)$ was subtracted from $\beta_{\mathrm{H}}$ of the homogenate as proposed by Pörtner (1990). The buffer value of fluoride was not considered in the calculations because the apparent dissociation constant of hydrofluoric acid (2.83.2 ) in the given range of temperature and ionic strength is far enough from the $\mathrm{pH}$ of the tissue homogenate to have only negligible influence on its buffer value (Pörtner 1990). The resulting value was corrected by the dilution factor of the tissue in the homogenate water (including medium and tissue water, the amount of water added with $\mathrm{HCl}$ and derived from neutralisation of calcium carbonate) to obtain $\beta_{\mathrm{NB}, \mathrm{NPi}}$ of the tissue $\left(\mathrm{mmol} \mathrm{pH} \mathrm{pg}^{-1} \mathrm{~kg}^{-1}\right.$ wet tissue weight).

Unfortunately, the exact determination of total $\mathrm{CO}_{2}$ in samples by the gas chromatography technique was impossible due to the high mucus content of the tissue homogenate which interfered with the measurements. Therefore, the solubility coefficient of $\mathrm{CO}_{2}$ and the bicarbonate concentration in the homogenate were calculated using temperature, total molarity and $\mathrm{PCO}_{2}$ according to the formula proposed by Heisler (1986). Tissue concentrations of $\mathrm{Na}^{+}$and $\mathrm{K}^{+}\left(126 \mathrm{mEq} \mathrm{g}^{-1}\right.$ and $94 \mathrm{mEq} \mathrm{g}^{-1}$ wet tissue weight, respectively) for Littorina spp. were adopted from a study on the foot muscle of White Sea L. littorea (Mikhailova et al. 1979). Calcium and magnesium ions were assumed to be bound to NTA in the homogenate. Additionally, data on tissue molarity $\left(0.5607 \mathrm{mmol} \mathrm{l}^{-1}\right.$ tissue water) and protein concentration (180 $\mathrm{g} \mathrm{l}^{-1}$ tissue water) of Sipunculus nudus (Pörtner 1982) were used in the calculations. Due to the high degree of dilution of tissue by the KF + NTA medium, variation in the latter has only minor influence on the calculated intracellular buffer values. All concentrations were corrected for dilution by medium and tissue water, as well as water added with $\mathrm{HCl}$ and derived from neutralisation of calcium carbonate. Tissue water content was measured for the foot of L. littorea as the difference between tissue wet weight and dry weight obtained after drying at $80{ }^{\circ} \mathrm{C}$ for $24 \mathrm{~h}$. Average tissue water content was $76.43 \pm 0.027 \%(n=60)$ and did not significantly change after 5 days of freshwater exposure. This value was applied in subsequent calculations for all three species. 
Additionally, tissue $\mathrm{CaCO}_{3}$ buffer value $\left(\beta_{\mathrm{CaCO}_{3}}\right)$ was calculated as follows:

$\beta_{\mathrm{CaCO}_{3}}=\frac{3000 \times \mathrm{V}_{\mathrm{HCl}}}{\Delta \mathrm{pH} \times \mathrm{W}_{\mathrm{tiss}}}\left(\mathrm{mmol} \mathrm{pH}{ }^{-1} \mathrm{~kg}^{-1}\right)$

where $V_{\mathrm{HCl}}$ is the volume (1) of $3 \mathrm{~mol}^{-1} \mathrm{HCl}$ used for the back titration of the homogenate to physiological $\mathrm{pH}$ values, $\Delta \mathrm{pH}$ is the difference between the initial homogenate $\mathrm{pH}$ and that reached after $\mathrm{HCl}$ titration, and $\mathrm{W}_{\text {tiss }}$ is the tissue wet weight $(\mathrm{kg})$.

Chemicals

All chemicals were purchased from Sigma Chemical (St. Louis, Mo., USA) or Merck (Darmstadt, Germany).

\section{Proton balance}

The metabolic proton production $\Delta \mathrm{H}^{+}$met was calculated according to Pörtner $(1987 \mathrm{a}, \mathrm{b})$ using the data from our companion study (Sokolova et al. 2000). It was assumed that succinate accumulation is coupled to a production of $2 \mathrm{~mol} \mathrm{H}^{+} \mathrm{mol}^{-1}$, and ATP hydrolysis releases $0.43 \mathrm{~mol} \mathrm{H}^{+} \mathrm{mol}^{-1}$ at $\mathrm{pH} 6.9$ (Pörtner 1987a). Influence of phosphagen depletion on proton balance was calculated considering the proton binding by the phosphate buffer at the final $\mathrm{pH}_{\mathrm{i}}$ after 3 days or 5 days of freshwater exposure. The fraction of protonated phosphate (F) was calculated using Eq. 3 for $\mathrm{pKa}$ $\left(8^{\circ} \mathrm{C}\right)=6.842$ (Pörtner 1990):

$F=\frac{1}{10^{\mathrm{pH}-\mathrm{pKa}}+1}$

Non-respiratory proton quantities $\left(\Delta \mathrm{H}^{+}{ }_{\text {non-resp }}\right)$ were deduced from non-bicarbonate buffer lines on $\Delta \mathrm{H}^{+}$versus $\mathrm{pH}_{\mathrm{i}}$ plots. This procedure estimates a proton load to the tissue under the assumption that the observed $\mathrm{pH}_{\mathrm{i}}$ changes are negligibly influenced by the bicarbonate system at low $\mathrm{pH}_{\mathrm{i}}$. Hence, any discrepancies between $\Delta \mathrm{H}^{+}{ }_{\text {non-resp }}$ and $\Delta \mathrm{H}^{+}{ }_{\text {met }}$ are assumed to represent the effects of other acid-base relevant processes like proton-equivalent ion transfer, calcium carbonate buffering, etc. (Pörtner 1987b).

\section{Statistics}

Statistical treatment was performed using standard Model I ANOVA procedures after testing the assumptions of normal distribution and homogeneity of variance of the data (Sokal and Rohlf 1995). We used Tukey's honestly significant difference test for unequal $N$ as a method of post-hoc comparisons. For analyses of non-independent sequential measurements on the same samples obtained by ${ }^{31} \mathrm{P}-\mathrm{NMR}$, distribution-free statistical procedures were used (Kruskal-Wallis test statistics and sign test; Sokal and Rohlf 1995). For constructing paired data for sign test, samples of each species were randomised within respective levels of the factor "exposure duration". All differences were considered significant if the probability level of type I error was less than 0.05 . Results are expressed as mean $\pm \mathrm{SE}$.

\section{Results}

In vivo NMR spectroscopy: Method validation and general results

Figure 1 shows typical in vivo ${ }^{31} \mathrm{P}-\mathrm{NMR}$ spectra of the three Littorina species under control conditions. All spectra exhibit the characteristic signals of high-energy phosphates: PLA and adenosine-5'-triphosphate (ATP), as well as that of Pi and a large signal arising from the

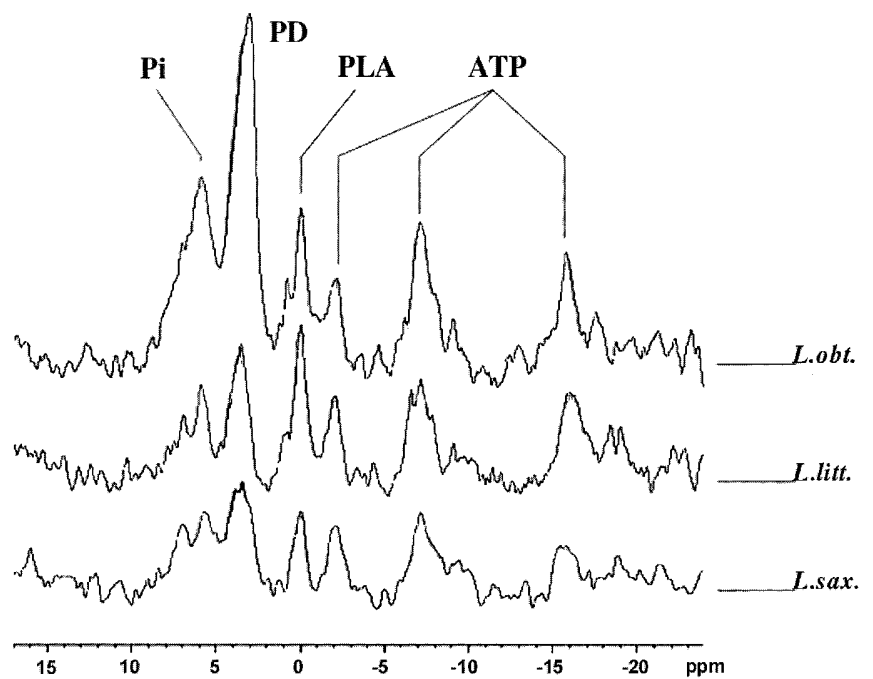

Fig. 1 In vivo ${ }^{31} \mathrm{P}$ nuclear magnetic resonance $\left({ }^{31} \mathrm{P}-\mathrm{NMR}\right)$ spectra of Littorina saxatilis, L. littorea and L. obtusata sampled under control conditions. Each spectrum was accumulated over $10 \mathrm{~min}$. Peaks are: $P L A$ phospho-L-arginine, ATP adenosine- 5 '-triphosphate, $P i$ inorganic phosphate, $P D$ phosphodiesthers

presence of phosphodiesters (PD). Although the phosphodiester signal seemed to be higher in the spectra of $L$. obtusata, no significant differences were found between the studied species $(P>0.05)$.

${ }^{31} \mathrm{P}-\mathrm{NMR}$ spectra (10-min acquisition period each) were collected repeatedly in L. saxatilis and L. littorea control samples demonstrating that signals remained unchanged and stable over a measurement period of almost $1 \mathrm{~h}$ and between repeated measurements during $24 \mathrm{~h}$ of control conditions.

It should be noted that the quality of spectra depends crucially on the conductivity and homogeneity inside the sample. The signal-to-noise $(\mathrm{S} / \mathrm{N})$ ratio varied between the spectra from control and freshwater-exposed animals as well as between the spectra obtained from different species. Considerably lower $\mathrm{S} / \mathrm{N}$ ratios in spectra under control conditions were evidently due to the higher conductivity of seawater that decreased the performance of the NMR probe and furthermore, a higher inhomogeneity due to animal movements in control samples. This resulted in a broader line width of the signals in comparison to samples measured in freshwater. Impaired homogeneity in samples consisting of numerous small animals (as in L. saxatilis or L. obtusata) also led to a decrease in the $\mathrm{S} / \mathrm{N}$ ratio as compared to samples containing few large L. littorea. Nevertheless, this does not influence estimation of relative peak areas and/or position of the peaks within one spectrum but would have a marked impact on calculations of absolute peak areas and their transformation into concentration units. Therefore, we only determined ratios of energyrelevant phosphorus compounds and intracellular $\mathrm{pH}_{\mathrm{i}}$ values from the chemical shift of the inorganic phosphorus signal. We also calculated free $\mathrm{Mg}^{2}+$ concentrations for calculations of the Gibbs free-energy change of ATP hydrolysis (Sokolova et al. 2000). 


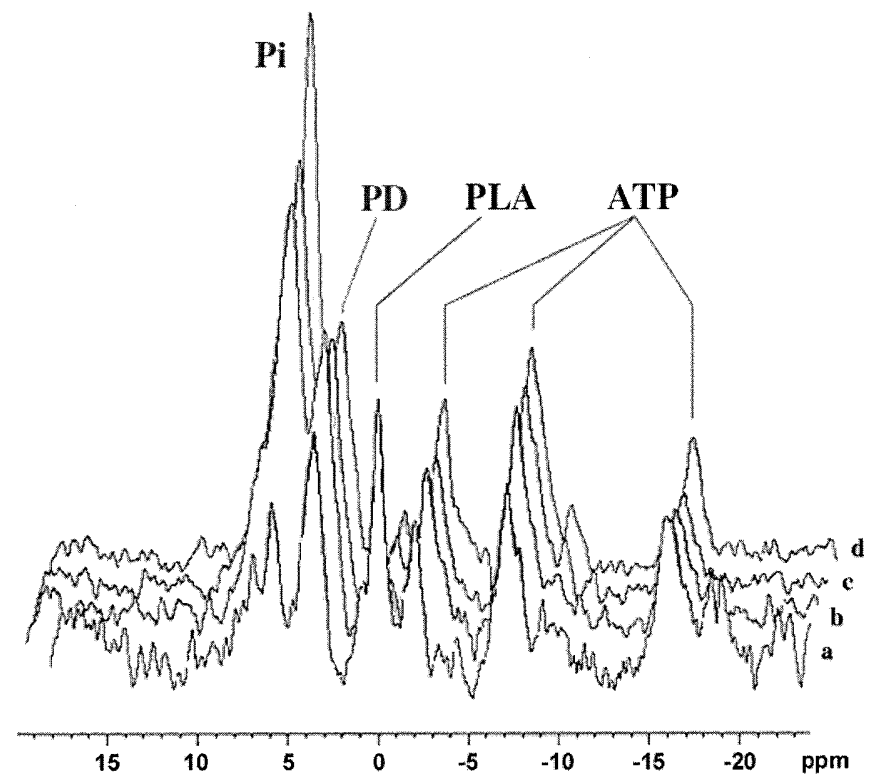

Fig. 2 Typical stack plot of in vivo ${ }^{31} \mathrm{P}-\mathrm{NMR}$ spectra from $L$. littorea over all incubation periods. $a$ control conditions; $b, c, d$ 3 days, 5 days and 7 days of freshwater exposure, respectively. Note that the peak of inorganic phosphate $\left(\mathrm{P}_{\mathrm{i}}\right)$ increased and shifted to low field indicating a more acidic intracellular $\mathrm{pH}$ value. PLA signal decreased during freshwater exposure and practically vanished at days 5 and 7

A typical stack plot of in vivo ${ }^{31} \mathrm{P}-\mathrm{NMR}$ spectra from L. littorea over all incubation periods is presented in Fig. 2. Spectrum a was accumulated under control conditions. After 3 days of hypoosmotic stress (spectrum $b$ ) the peak of $P_{i}$ increased and shifted indicating a more acidic intracellular $\mathrm{pH}$ value. The PLA peak decreased, whereas the ATP signal remained almost constant throughout all exposure periods. After 5 days and 7 days of incubation the $\mathrm{P}_{\mathrm{i}}$ signal rose even further (spectra c, d), and the PLA signal decreased. These changes are reflected in the dynamics of $\mathrm{P}_{\mathrm{i}} / \mathrm{PLA}$ and $\mathrm{P}_{\mathrm{i}} /$ $\beta$ ATP ratios which showed large and statistically significant increases in freshwater exposed animals as compared to controls in all studied species (Fig. 3).

\section{Intracellular $\mathrm{pH}$}

Average levels of $\mathrm{pH}_{\mathrm{i}}$ as estimated by in vivo ${ }^{31} \mathrm{P}-\mathrm{NMR}$ spectroscopy were similar in the studied species under control conditions (K-W test, $P>0.65$ ) and varied between 7.45 and 7.56. During freshwater exposure a drastic drop in $\mathrm{pH}_{\mathrm{i}}$ was observed (Fig. 4A). After 3 days of freshwater exposure $\mathrm{pH}_{\mathrm{i}}$ had declined by 0.4 0.5 units. Further $\mathrm{pH}_{\mathrm{i}}$ changes were small and remained insignificant between conspecifics at later exposure periods $(\mathrm{K}-\mathrm{W}, P>0.10)$. In a between-species comparison, there is a trend for $\mathrm{pH}_{\mathrm{i}}$ to decrease faster and reach lower values in the least resistant species L. obtusata. The rate of reduction and $\mathrm{pH}_{\mathrm{i}}$ levels reached were intermediate in $L$. saxatilis. The slowest rate and highest
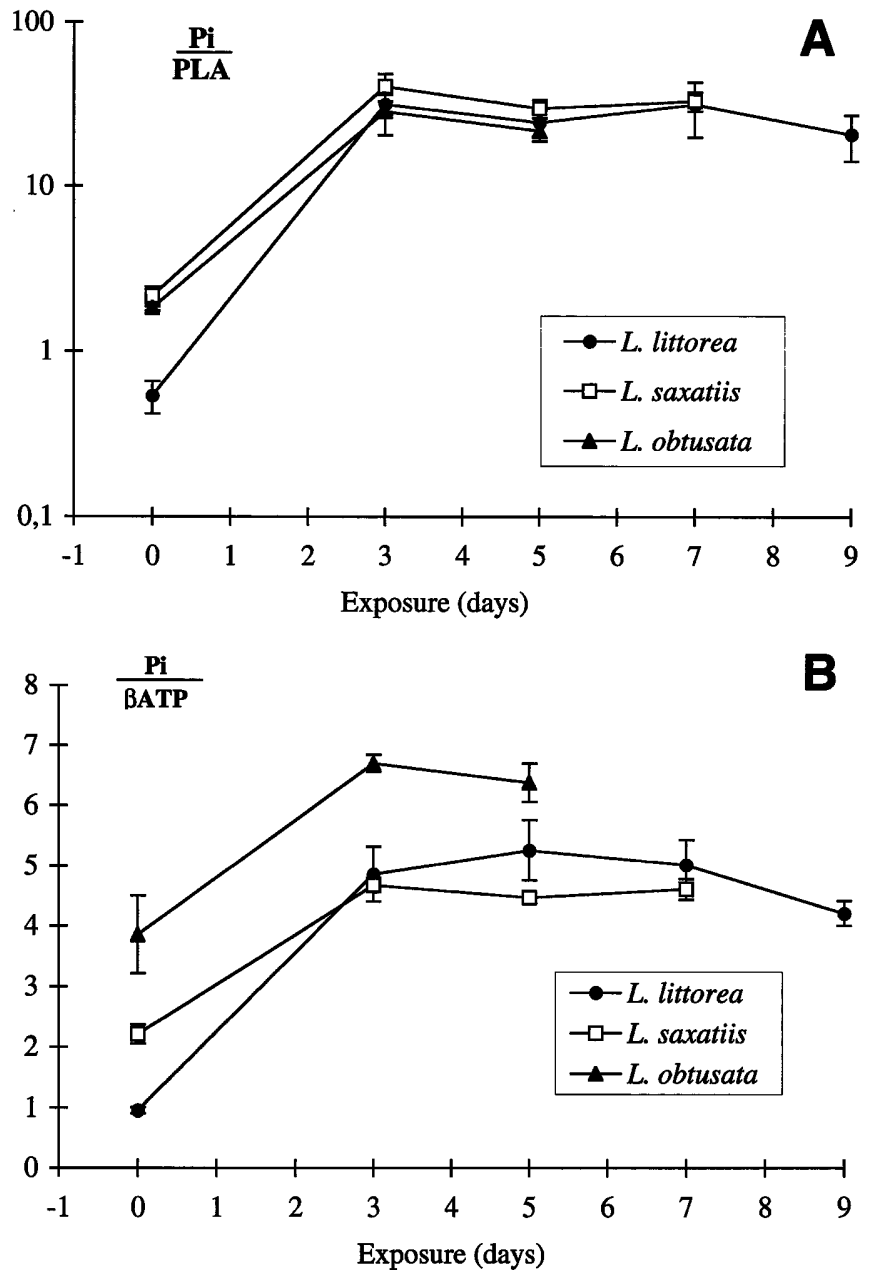

Fig. 3 Changes of NMR indices in White Sea Littorina spp. during freshwater exposure: $\mathbf{A} \mathrm{P}_{\mathrm{i}} / \mathrm{PLA} ; \mathbf{B} \mathrm{P}_{\mathrm{i}} / \beta \mathrm{ATP}$. Data are means of five samples measured for each exposure period, except for 7 days in $L$. littorea $(n=10)$. Increases in the NMR indices in freshwaterexposed animals are statistically significant compared to controls. Vertical bars represent standard errors

$\mathrm{pH}_{\mathrm{i}}$ values were observed in the most resistant $L$. littorea (Fig. 4A). However, a sign test showed that differences in $\mathrm{pH}_{\mathrm{i}}$ were only statistically significant between the least resistant $L$. obtusata and the most resistant $L$. littorea.

Calculation of intracellular free $\mathrm{Mg}^{2+}$ concentration from in vivo ${ }^{31} \mathrm{P}-\mathrm{NMR}$ spectra resulted in average means of about $0.7 \mathrm{mmol}^{-1}$ (range $\left.0.55-0.84 \mathrm{mmol} \mathrm{l}^{-1}\right)$ in the three Littorina spp. studied (Fig. 4B). Variability was large in control samples of L. obtusata and L. saxatilis due to difficulties determining the exact position of the peak in rather broad $\beta$-ATP signals (data not shown). However, changes in $\mathrm{Mg}^{2+}$ concentrations during long-term incubation were minor and insignificant between species, and between different exposure periods.

\section{Tissue buffer capacity}

Non-bicarbonate, non-phosphate buffer values measured in homogenates of foot tissues varied between 

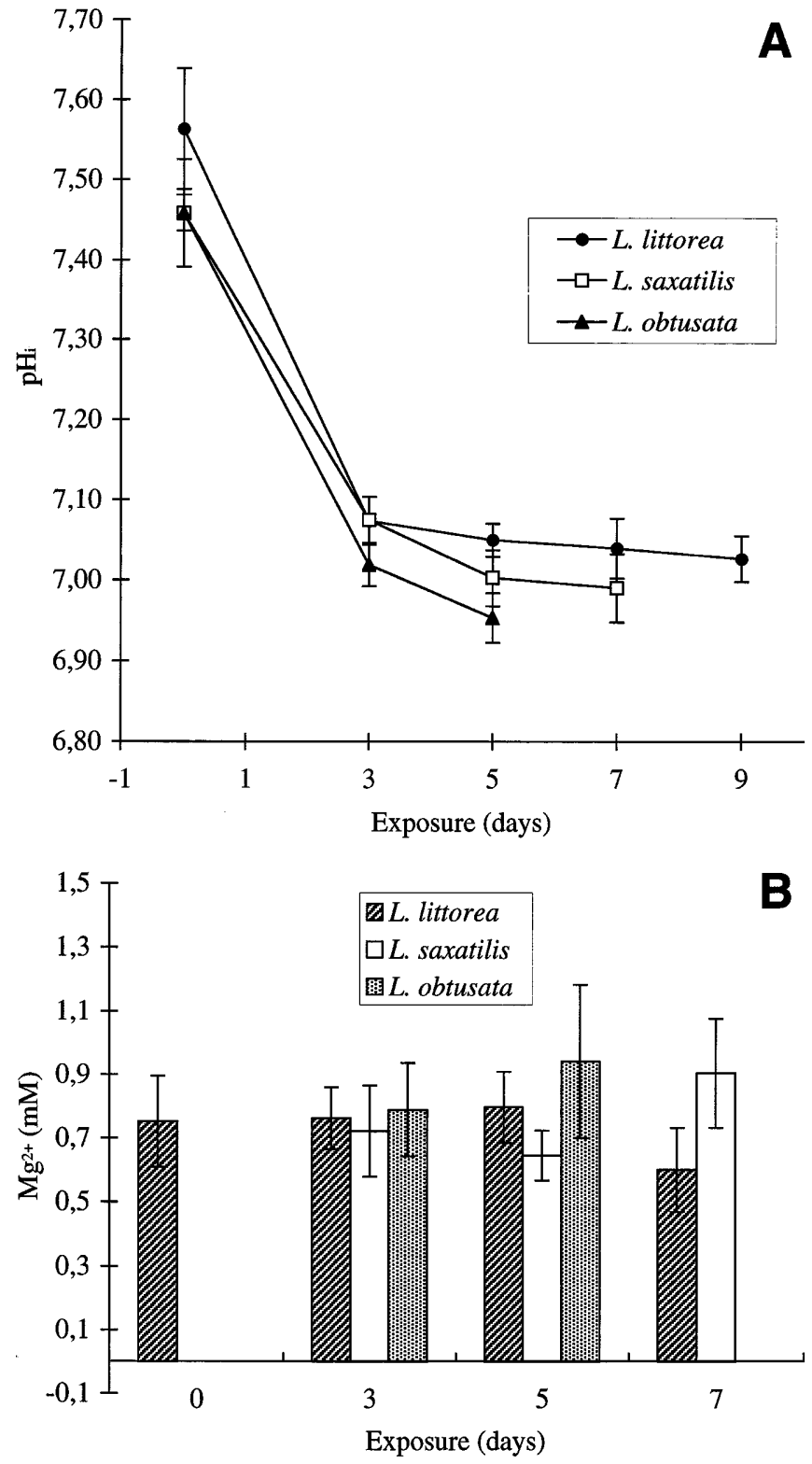

Fig. 4 Intracellular $\mathrm{pH}(\mathbf{A})$ and free magnesium concentrations (B) calculated from ${ }^{31} \mathrm{P}-\mathrm{NMR}$ spectra in White Sea Littorina spp. during freshwater exposure. Data are means of five samples measured per exposure period, except for 7 days in L. littorea $(n=10)$. Vertical bars represent standard errors. Intracellular $\mathrm{pH}$ $\left(\mathrm{pH}_{\mathrm{i}}\right)$ was significantly below control values for all exposure periods. Intracellular concentration of free $\mathrm{Mg}^{2+}$ did not change significantly during freshwater exposure in either species

$28.5 \mathrm{mmol} \mathrm{pH}^{-1} \mathrm{~kg}^{-1}$ and $42.8 \mathrm{mmol} \mathrm{pH}^{-1} \mathrm{~kg}^{-1}$ wet weight. However, two statistically significant outliers

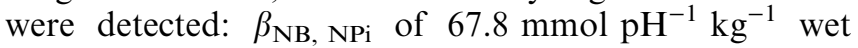
weight (a sample of $L$. saxatilis foot tissues after 5 days

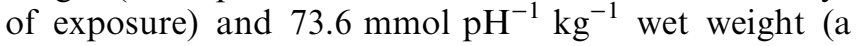
sample of L. obtusata under control conditions). No significant differences in $\beta_{\mathrm{NB}, \mathrm{NPi}}$ values were found between studied species nor between control and exposed animals (ANOVA, $P>0.05$ ) regardless of whether outliers were rejected or not. Mean $\beta_{\mathrm{NB}, \mathrm{NPi}}$ (outliers excluded) are given in Fig. 5A.
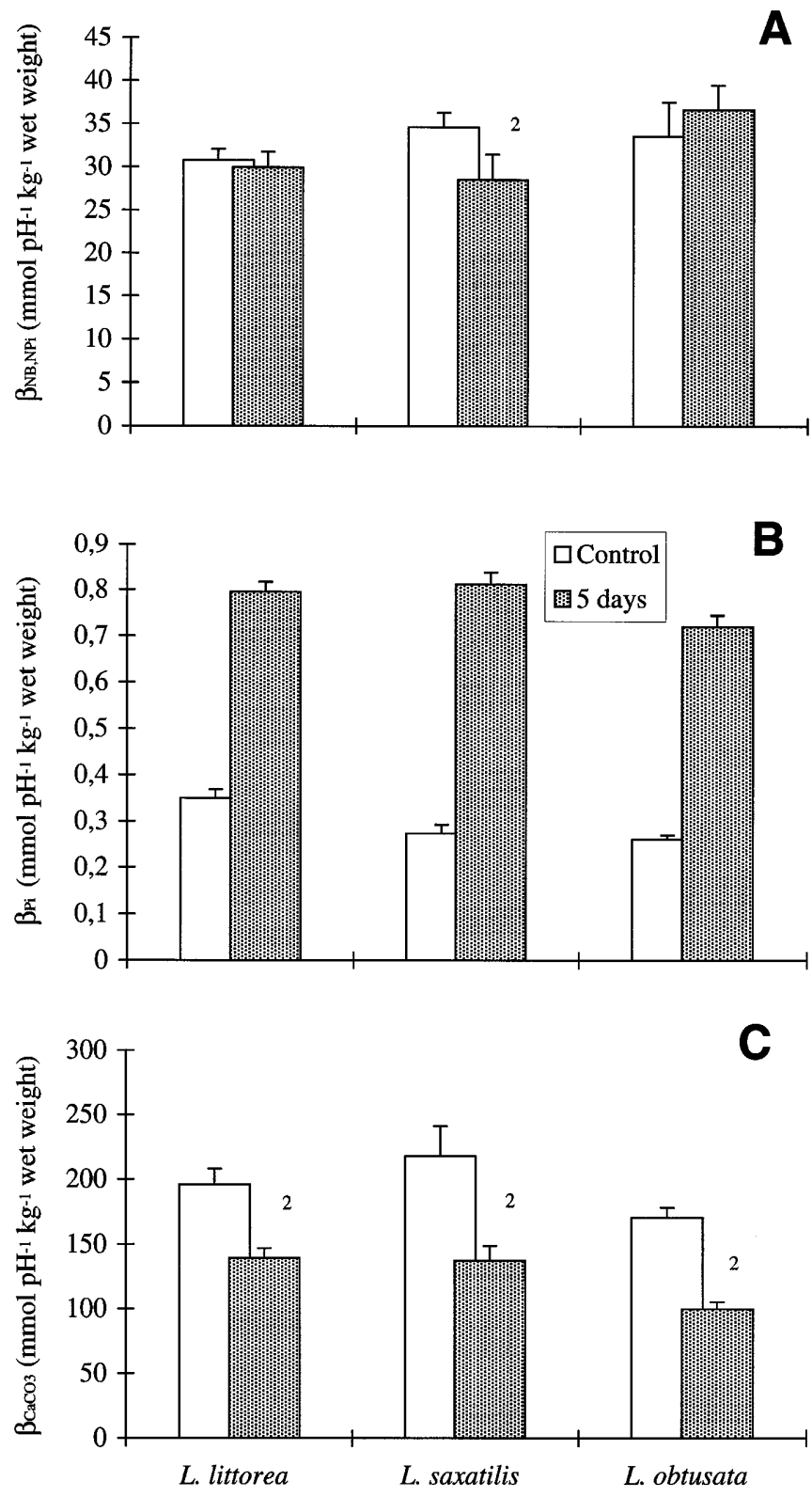

Fig. 5 Foot muscle non-bicarbonate, non-phosphate $\left(\beta_{\mathrm{NB}, \mathrm{NPi}}\right)(\mathbf{A})$, $\mathrm{P}_{\mathrm{i}}\left(\beta_{\mathrm{Pi}}\right)(\mathbf{B})$ and calcium carbonate $\left(\beta_{\mathrm{CaCO} 3}\right)(\mathbf{C})$ buffer values of White Sea periwinkles during freshwater exposure. $n=6-10$ (control) or 2-4 (5 days). Vertical bars represent standard errors or range (for $n=2$ )

Buffer values of $P_{i}$ increased significantly during freshwater exposure in all three species studied

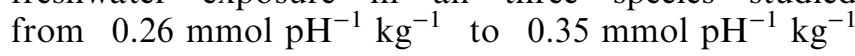
wet weight under control conditions to 0.72 $0.81 \mathrm{mmol} \mathrm{pH}^{-1} \mathrm{~kg}^{-1}$ wet weight after 5 days of freshwater exposure (ANOVA, factorial effect of "freshwater exposure": $P<0.0001)$. There were also species-specific differences in the value of $\beta_{\mathrm{Pi}}$ in controls, the level of $\beta_{\mathrm{Pi}}$ being the highest in L. littorea $(P<0.001)$. No differences in $\beta_{\mathrm{Pi}}$ were found between studied species after 5 days of freshwater exposure (Fig. 5B).

Tissue calcium carbonate buffer values $\left(\beta_{\mathrm{CaCO}_{3}}\right)$ were considerably higher than $\beta_{\mathrm{NB}, \mathrm{NPi}}$ (Fig. 5C) and varied 

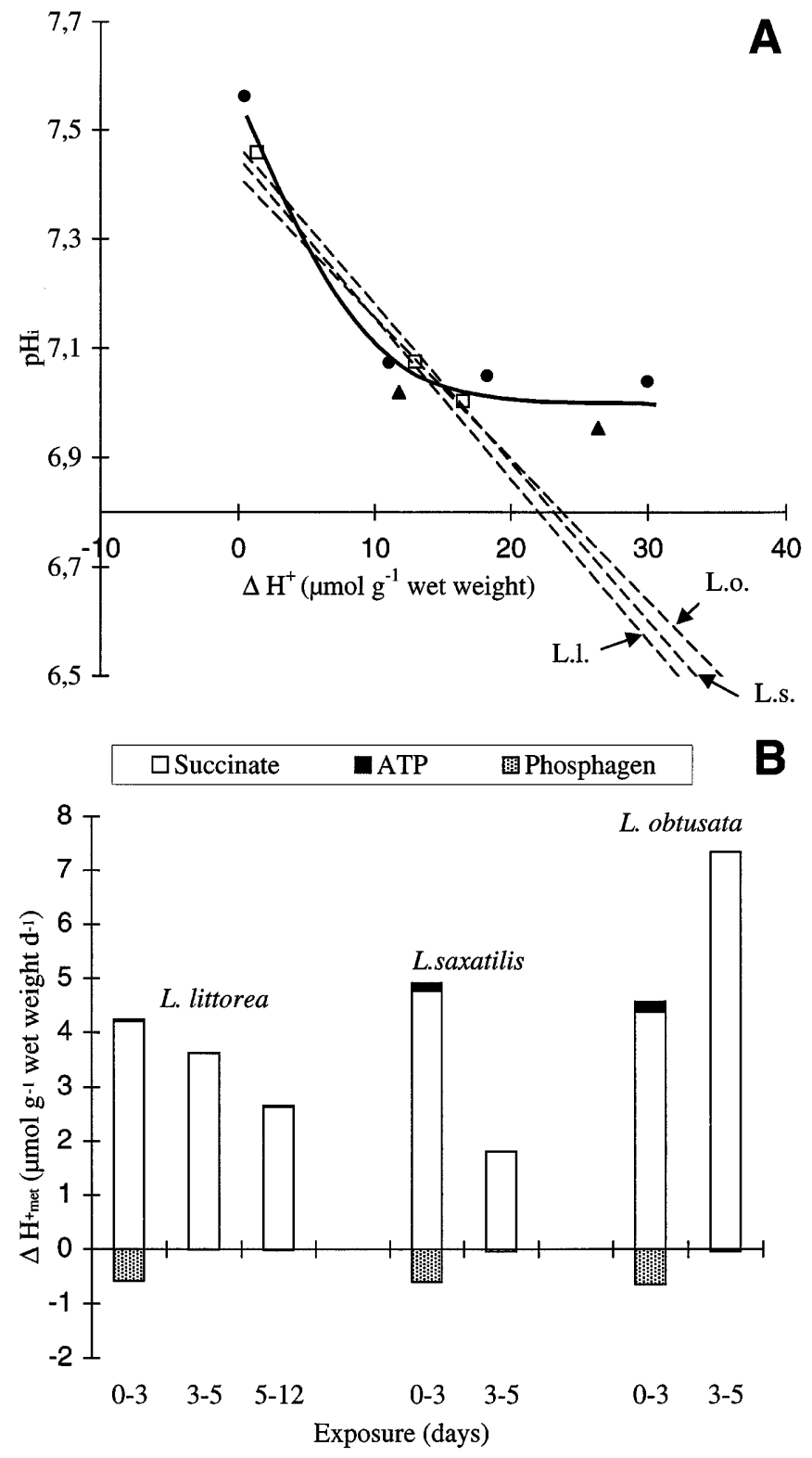

Fig. 6 Relationship between metabolic proton accumulation and $\mathrm{pH}_{\mathrm{i}}$ (A) and contribution of different metabolic processes to the metabolic proton load (B) during freshwater exposure in Littorina spp. A The relationship between $\mathrm{pH}_{\mathrm{i}}$ and cumulative metabolic proton change $\left(\Delta \mathrm{H}^{+}{ }_{\text {met }}\right)$ reflects the effective buffer value of the tissue for metabolic protons and quantifies the extent to which protons are buffered in vivo. Filled circles: L. littorea; filled triangles: L. saxatilis; open squares: L. obtusata. Non-bicarbonate buffer lines $\left(\beta_{\mathrm{H}}\right)$ determined in vitro for L. littorea (L.l.), L. saxatilis (L.s.) and L. obtusata (L.o.) (dotted lines) reflect physicochemical buffering starting from the respective control $\mathrm{pH}_{\mathrm{i}}$ values. Note that during the initial phase of freshwater exposure (days $0-3$ ) the drop in $\mathrm{pH}_{\mathrm{i}}$ is close to or even somewhat larger than expected from non-bicarbonate tissue buffering alone, whereas later on the $\mathrm{pH}_{\mathrm{i}}$ appears to be efficiently positively regulated probably due to calcium carbonate buffering. B Proton changes due to the production of succinate and cleavage of ATP and phosphagen are shown. All calculations are based on the mean changes of metabolite concentrations for the respective periods between 148.2 and $277.3 \mathrm{mmol} \mathrm{pH}^{-1} \mathrm{~kg}^{-1}$ wet weight in control snails and between $94.7 \mathrm{mmol} \mathrm{pH} \mathrm{mg}^{-1} \mathrm{~kg}^{-1}$ and $148.7 \mathrm{mmol} \mathrm{pH}^{-1} \mathrm{~kg}^{-1}$ wet weight in exposed snails. As shown by two-way ANOVA, the factor "freshwater exposure" had a significant influence on $\beta_{\mathrm{CaCO}}$ values of the foot tissues of Littorina spp. $(P<0.001)$. In general, calcium carbonate buffer values of Littorina spp. foot tissues decreased after 5 days of freshwater exposure as compared to the respective control levels (Fig. 5C). Between-species differences in $\beta_{\mathrm{CaCO}_{3}}$ were not significant neither in the control, nor after 5 days of freshwater exposure $(P>0.07)$.

\section{Proton balance}

$\Delta \mathrm{H}^{+}{ }_{\text {met }}$ in the studied Littorina spp. varied between $11 \mu \mathrm{mol} \mathrm{H}{ }^{+} \mathrm{g}^{-1}$ and $14 \mu \mathrm{mol} \mathrm{H}{ }^{+} \mathrm{g}^{-1}$ wet weight after 3 days of freshwater exposure and up to ca. $30 \mu \mathrm{mol}$ $\mathrm{H}^{+} \mathrm{g}^{-1}$ wet weight at the end of the experiment (Fig. 6A). Substantial increase in the metabolic proton load over time during freshwater exposure was predominantly a result of succinate accumulation (Fig. 6B). Contribution of phosphagen depletion to the total metabolic proton balance was relatively small, and that of ATP breakdown practically negligible, in particular during sustained freshwater exposure (Fig. 6B).

Between-species comparisons of the rates of metabolic proton production suggest that in the two more resistant species (L. littorea and L. saxatilis) the increase in metabolic proton load was lower during sustained anaerobiosis as compared to the early period of freshwater exposure (Fig. 6B). In contrast, the rate of metabolic proton production in the most susceptible L. obtusata increased considerably during the later stage of anaerobic exposure.

In general, intracellular $\mathrm{pH}_{\mathrm{i}}$ was negatively related to the metabolic proton load. However, the rate of $\mathrm{pH}_{\mathrm{i}}$ decrease changed considerably over the freshwater exposure period. During the first 3 days of freshwater exposure a fast and drastic drop in $\mathrm{pH}_{\mathrm{i}}$ was observed with a rate close to or even slightly higher than expected from the exclusive buffering by the non-bicarbonate tissue buffers (Fig. 6A). Later on during freshwater exposure the rate of acidification of the intracellular milieu slowed down significantly despite continuing metabolic proton production. In fact, intracellular $\mathrm{pH}$ of Littorina spp. remained fairly constant over a wide range of cumulative metabolic acidification between $11 \mu \mathrm{mol} \mathrm{H}^{+} \mathrm{g}^{-1}$ and $30 \mu \mathrm{mol} \mathrm{H}^{+} \mathrm{g}^{-1}$ wet weight. At the highest proton loads ( $>20 \mu \mathrm{mol} \mathrm{H} \mathrm{H}^{+} \mathrm{g}^{-1}$ wet weight) the drop in $\mathrm{pH}_{\mathrm{i}}$ was less than expected from non-bicarbonate tissue buffering alone by approximately $0.2-0.4 \mathrm{pH}$ units (Fig. 6A).

\section{Discussion}

\section{In vivo NMR spectra}

Changes of energy-relevant NMR ratios during freshwater exposure of White Sea Littorina spp. were in 
qualitative agreement with the biochemically determined changes of high-energy compounds in the tissues of the studied species (Sokolova et al. 2000). Ratios of $\mathrm{P}_{\mathrm{i}} /$ PLA and $\mathrm{P}_{\mathrm{i}} / \beta$ ATP increased significantly in freshwater exposed animals as compared to controls, thus reflecting impaired energy status of the experimental snails.

Analysis of ${ }^{31} \mathrm{P}$-NMR spectra showed that $\mathrm{P}_{\mathrm{i}}$ concentrations were rather high under control conditions in Littorina spp. Presence of high concentrations of $\mathrm{P}_{\mathrm{i}}$ in the tissue is generally considered to indicate stressful conditions (e.g. van den Thillart and van Waarde 1996) The experimental design used in our study may have imposed a certain degree of stress due to crowding and restrained movements of the snails during acquisition of the NMR spectra. However, repeated measurements of ${ }^{31} \mathrm{P}-\mathrm{NMR}$ spectra showed no changes over time during control conditions in the magnet. This observation suggests that stress had only minimal effects on the animals. Additionally, rather high $\mathrm{P}_{\mathrm{i}}$ concentrations were found in tissue extracts of control animals which experienced no crowding (Sokolova et al. 2000). Therefore, relatively high $\mathrm{P}_{\mathrm{i}}$ levels in Littorina spp. under control conditions may reflect a higher content of NMR-visible phosphorus compounds including $\mathrm{P}_{\mathrm{i}}$ in these species, which is a well-known feature in some invertebrates (van den Thillart and van Waarde 1996).

Comparison of ${ }^{31} \mathrm{P}-\mathrm{NMR}$ spectra obtained from Littorina spp. after different periods of freshwater exposure clearly demonstrates an increase in intracellular $P_{i}$ concentrations in freshwater-exposed animals. This partially contrasts our previous invasive study (Sokolova et al. 2000) which showed relatively small (and only statistically significant in some species) increases in $\mathrm{P}_{\mathrm{i}}$ contents in the foot tissues of the periwinkles under conditions of hypoosmotic stress. Reasons for this were discussed elsewhere (Sokolova et al. 2000). However, it should be noted that the increase in $P_{i}$ concentrations observed in ${ }^{31} \mathrm{P}-\mathrm{NMR}$ spectra was higher than the decrease in PLA contents and suggests that there must have been other sources of $\mathrm{P}_{\mathrm{i}}$ mobilisation during freshwater exposure in the studied Littorina spp. This change was not visible in tissue extracts (Sokolova et al. 2000) and indicates a change in free $P_{i}$ concentration. Possibly the release of free $P_{i}$ ions occurred from an insoluble complex of calcium phosphate at low intracellular pH (Weich et al. 1989), as phosphates are known to be components of the calcium carbonate granules found in connective tissue cells of molluscs (Mason et al. 1984). This suggestion is indirectly supported by the observed decrease of calcium carbonate buffer values in the foot in Littorina spp., which probably indicates mobilisation of material from tissue calcium carbonate granules during hypoosmotic stress. Nevertheless, further experiments must be performed to verify this hypothesis.

Interestingly, intracellular $\mathrm{Mg}^{2+}$ concentrations as determined by the non-invasive ${ }^{31} \mathrm{P}-\mathrm{NMR}$ technique, appear to be efficiently regulated in White Sea periwinkles. Free $\mathrm{Mg}^{2+}$ content is maintained at fairly constant levels of ca. $0.6-0.8 \mathrm{mmol} \mathrm{l}^{-1}$ even during prolonged anaerobiosis when many other crucial parameters of the intracellular milieu (including $\mathrm{pH}_{\mathrm{i}}$, energy status, etc.) undergo significant changes. Moreover, intracellular $\mathrm{Mg}^{2+}$ levels appear to be highly conserved between species of the genus Littorina studied. This finding is in accordance with the important role that this ion plays in many cellular processes (Simkiss and Mason 1983; Frederich et al. 2000).

Acid-base status and anaerobic metabolic rate

Even though NMR spectroscopy was able to provide only a qualitative picture of the changes in energy status, it was the only method allowing the determination of intracellular $\mathrm{pH}$, which is crucial for investigating the acid-base status during prolonged anaerobiosis caused by freshwater exposure in Littorina spp. The homogenate technique of $\mathrm{pH}_{\mathrm{i}}$ analysis (Pörtner et al. 1990) was not applicable in the calcium carbonate-rich tissues of White Sea Littorina spp.

Onset of anaerobiosis during freshwater exposure resulted in a substantial intracellular acidification in the three Littorina spp. studied. Intracellular $\mathrm{pH}$ dropped considerably at the beginning of freshwater exposure, with high rates of acidification during the first 3 days of exposure. Later on $\mathrm{pH}_{\mathrm{i}}$ levelled off in $L$. saxatilis and $L$. littorea but not in L. obtusata, although differences in $\mathrm{pH}_{\mathrm{i}}$ values between different exposure periods were not statistically significant in either species. This finding suggests that the periwinkles are able to regulate intracellular $\mathrm{pH}$ during anaerobiosis. In general, anaerobic $\mathrm{pH}$ regulation was most efficient in the most resistant species, L. littorea, as compared to L. saxatilis and especially L. obtusata.

Changes in intracellular $\mathrm{pH}$ values can theoretically be attributed to several processes, including (1) net proton production or consumption in metabolic reactions, (2) tissue proton buffering, (3) proton-equivalent transmembrane and transepithelial ion transfer, and (4) respiratory processes. The impact of respiratory proton production on acid-base balance of the snails could not be investigated since application of the homogenate technique was not possible (see above). However, the analysis of proton balance suggests a close correlation between $\mathrm{pH}_{\mathrm{i}}$ changes observed and those expected from metabolic acidification and tissue buffering capacity (Fig. 6). Moreover, measurements of the oxygen consumption rates of Littorina spp. in freshwater show that there is no respiration detectable under these conditions (I. Sokolova, unpublished data). Therefore, the respiratory influence on acid-base balance of the snails can be considered small.

Proton buffering in the foot tissues of White Sea Littorina spp. was provided by multiple buffer systems including $\mathrm{P}_{\mathrm{i}}$, imidazole groups of proteins and probably oligopeptides (which are generally believed to contribute to non-bicarbonate, non-phosphate tissue buffering; 
Eberlee and Storey 1984) and, most importantly, $\mathrm{CaCO}_{3}$. Our data showed that the proton-buffering systems differ and shift in their contribution to tissue buffering during freshwater/anoxia exposure. This complex pattern reflects the potential for an efficient $\mathrm{pH}_{\mathrm{i}}$ regulation during prolonged anaerobiosis in the periwinkles. Average values of $\beta_{\mathrm{NB}, \mathrm{NPi}}$ varied between

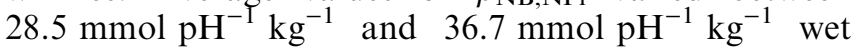
weight in the Littorina spp. studied and were in the low range reported for other invertebrate and lower vertebrate species, possibly for methodological reasons (Eberlee and Storey 1984; Heisler 1986; Wiseman and Ellington 1989; Zange et al. 1990; Ellington 1993; Pörtner 1990; Pörtner at al. 1996; van Dijk et al. 1997). Exposure to an extremely hypoosmotic environment for 5 days had no effect on $\beta_{\mathrm{NB}, \mathrm{NPi}}$ values of the periwinkles. In general, no correlation was found between freshwater resistance and $\beta_{\mathrm{NB}, \mathrm{NPi}}$ of foot tissues in the species studied, suggesting that differential resistance to freshwater and the discrepancy in the time-course of $\mathrm{pH}_{\mathrm{i}}$ changes between White Sea Littorina spp. could not be accounted for by the variations in $\beta_{\mathrm{NB}, \mathrm{NPi}}$.

The buffer values for $\mathrm{P}_{\mathrm{i}}$ were low in the three studied species $\left(<1 \mathrm{mmol} \mathrm{pH} \mathrm{H}^{-1} \mathrm{~kg}^{-1}\right.$ wet weight) under control conditions as well as after freshwater exposure. The increase in $\beta_{\mathrm{Pi}}$ after 5 days of freshwater exposure was partially a result of a moderate elevation in $\mathrm{P}_{\mathrm{i}}$ concentration (by ca. 27\%) found in ultrafiltrated homogenate samples from freshwater exposed animals as compared to controls. This increase was evidently due to the cleavage of phosphagen and adenylate compounds during freshwater exposure (Sokolova et al. 2000). In addition, the twofold elevation of $\beta_{\mathrm{Pi}}$ in freshwater-exposed animals is related to tissue acidification which brings $\mathrm{pH}_{\mathrm{i}}$ close to the apparent dissociation constant of $\mathrm{H}_{2} \mathrm{PO}_{3}$.

High initial $\mathrm{pH}$ values of tissue homogenates of Littorina spp. far exceeded in vivo $\mathrm{pH}_{\mathrm{i}}$ determined by ${ }^{31} \mathrm{P}$ NMR and were in the range of 8.4-8.6. These high $\mathrm{pH}$ values can most likely be explained by the presence of crystalline $\mathrm{CaCO}_{3}$ stored in connective tissue calcium cells of the foot (Mason et al. 1984; Brough and White 1990) and possibly, also by $\mathrm{CaCO}_{3}$ inclusions in the mucus produced by the foot epithelium of these species (Davies and Hutchinson 1995). Buffer values of the $\mathrm{CaCO}_{3}$ stores were five to six times higher than $\beta_{\mathrm{NB}, \mathrm{NPi}}$ values of the tissues. Again, no species-specific differences were found neither under control conditions, nor after 5 days of freshwater exposure. The $\beta_{\mathrm{CaCO} 3}$ value decreased upon prolonged freshwater exposure in all species studied, thus indicating that part of this buffer was probably consumed during anaerobiosis. It is worth noting that an important role of shell $\mathrm{CaCO}_{3}$ mobilisation in the neutralisation of acidic anaerobic end products in molluscs, has repeatedly been stressed since early in this century (Collip 1921; Dugal 1939; Akberali et al. 1977; Byrne and McMahon 1991). This role has also been suggested for $\mathrm{CaCO}_{3}$ granules in the connective tissue calcium cells of gastropods (Mason et. al. 1984).
However, to the best of our knowledge, this is the first experimental indication that tissue $\mathrm{CaCO}_{3}$ stores of the foot support proton buffering during sustained anoxia.

Analysis of the contribution of different metabolic processes to the proton balance of the tissue (Fig. 6B) suggests that succinate formation predominantly caused the acidification. An incomplete assay of metabolites can be excluded since succinate was the only end product among all tested metabolites (including alanopine, strombine, lactate, acetate and propionate) which was found to accumulate in the foot tissues of the Littorina spp. studied (Sokolova et al. 2000). The priority of endproduct accumulation to cause metabolic acidification of intracellular milieu was previously also reported for other marine organisms including the squids Illex illecebrosus and Lolliguncula brevis (Pörtner et al. 1991a, 1996), the lugworm Arenicola marina (Sommer and Pörtner 2000) and the peanut worm Sipunculus nudus (Pörtner 1987b, Hardewig et al. 1991).

During the first 3 days, metabolic proton production was similar to or even lower than non-respiratory proton changes deduced from the actual changes in $\mathrm{pH}_{\mathrm{i}}$ and the non-bicarbonate tissue buffer values (Fig. 6A). The latter is an unexpected finding which suggests net proton uptake by the cells of Littorina spp. during the early stage of freshwater exposure, and may argue for a downregulation of intracellular $\mathrm{pH}$ during this period (Pörtner 1993). Considering a possible overestimation of the metabolic proton load due to the lack of data on ammonia concentrations, the discrepancy between $\Delta \mathrm{H}^{+}$met and $\Delta \mathrm{H}^{+}$non-resp may be even larger. For example, ammonia may bind between $5 \%$ and $20 \%$ of metabolic protons in temperature stressed lugworms Arenicola marina (Sommer and Pörtner 2000) and about $15 \%$ in anoxic peanut worms Sipunculus nudus (Pörtner 1987b). Later on during freshwater exposure, $\mathrm{pH}_{\mathrm{i}}$ appears to be strongly positively regulated and is maintained at fairly constant levels despite the increase in the cumulative metabolic proton load. The difference between expected non-respiratory and observed metabolic proton loads changed to positive values, such that expected $\Delta \mathrm{H}^{+}$non-resp was markedly higher than the observed acidification. This strongly indicates involvement of an additional mechanism in $\mathrm{pH}$ buffering, possibly ion transfer mechanisms and/or increased buffering by the $\mathrm{CaCO}_{3}$ system. It is worth noting that the role of transmembrane and transepithelial ion exchange mechanism is expected to be relatively small due to the depressed overall metabolic rate during environmental anaerobiosis (Pörtner et al. 1991b; Sokolova et al. 2000). It is highly probable that the reduction in accumulated proton quantities is mostly caused by the $\mathrm{CaCO}_{3}$ buffer system. This system is evidently not involved in $\mathrm{pH}_{\mathrm{i}}$ regulation during the early stages of freshwater exposure and becomes mobilised only when $\mathrm{pH}_{\mathrm{i}}$ drops to sufficiently low levels probably due to the increased solubility of calcium carbonate in an acidic medium. Comparison of the observed decrease in $\mathrm{pH}_{\mathrm{i}}$ (e.g. $\Delta \mathrm{pH}_{\text {obs }}$ of $0.1-0.15$ between $\Delta \mathrm{H}^{+}{ }_{\text {met }}$ of 
$10 \mu \mathrm{mol} \mathrm{g} \mathrm{g}^{-1}$ and $30 \mu \mathrm{mol} \mathrm{g}{ }^{-1}$ wet tissue weight) with those expected from non-bicarbonate tissue buffering alone (ca. $0.5-0.7 \mathrm{pH}$ units) suggests that additional proton buffering of between $40 \mu \mathrm{mol} \mathrm{H}^{+} \mathrm{pH}^{-1} \mathrm{~g}^{-1}$ and $50 \mu \mathrm{mol} \mathrm{H} \mathrm{H}^{+} \mathrm{pH}^{-1} \mathrm{~g}^{-1}$ wet weight is involved. This value is roughly equivalent to what would be expected from the observed decrease in $\beta_{\mathrm{CaCO}_{3}}$ during freshwater exposure of the periwinkles. This quantitative agreement between the observed decrease in the $\mathrm{CaCO}_{3}$ buffer value and the amount of the buffered metabolic protons evidences in favour of our hypothesis that a fraction of $\mathrm{CaCO}_{3}$ stores is consumed for $\mathrm{pH}_{\mathrm{i}}$ regulation during sustained anaerobiosis in White Sea Littorina spp.

In general, the observed dynamics of $\mathrm{pH}_{\mathrm{i}}$ changes versus metabolic and non-respiratory proton production may suggest that $\mathrm{pH}_{\mathrm{i}}$ regulation diverts from downregulation (or nearly no regulation) during early stages of environmental anaerobiosis to considerable positive regulation during sustained stress. Maintenance of lower set points of $\mathrm{pH}$ could help, on the one hand, to enhance the onset of metabolic arrest state during early anaerobiosis (Pörtner 1993), and on the other hand, to restrain fast acidification of the intracellular milieu caused by high metabolic proton production when anoxic conditions persist.

In conclusion, investigation of anaerobic metabolism during prolonged freshwater exposure in White Sea Littorina spp. reveals that various acid-base, metabolic and energy parameters are correlated and interconnected to provide the physiological basis for the remarkable freshwater resistance of periwinkles. During prolonged freshwater exposure, the change in $\mathrm{pH}_{\mathrm{i}}$ follows a complex pattern and suggests a high capacity for $\mathrm{pH}_{\mathrm{i}}$ regulation in the periwinkles, especially during sustained environmental anaerobiosis when high rates of succinate accumulation would otherwise lead to a deleterious extreme acidification of the intracellular space. The $\mathrm{pH}_{\mathrm{i}}{ }^{-}$ regulatory ability is probably in part provided by the multiple buffering systems present in the tissues of Littorina spp., especially by the $\mathrm{CaCO}_{3}$ buffer. Relative contribution of the multiple buffer systems to $\mathrm{pH}_{\mathrm{i}}$ regulation evidently changes during freshwater exposure. At the initial stage of freshwater exposure the nonbicarbonate, non-phosphate tissue buffering system seems to be of a major importance for the metabolic proton buffering at $\mathrm{pH}_{\mathrm{i}}$ between 7.5 and 7.0. During later stages of anaerobiosis and at lower $\mathrm{pH}_{i}$, the $\mathrm{CaCO}_{3}$ buffer is involved in proton buffering. A quantitative agreement between the decrease in the $\mathrm{CaCO}_{3}$ buffer value and the quantity of buffered metabolic protons suggests that $\mathrm{CaCO}_{3}$ tissue stores may serve as a major buffering system during prolonged anaerobiosis in Littorina spp. Species-specific differential resistance to extreme hypoosmotic stress can be attributed to the improved abilities for metabolic arrest (Sokolova et al. 2000), as well as to the increased ability to regulate $\mathrm{pH}_{\mathrm{i}}$ and to defend relatively higher levels of energy potential of ATP in the more resistant species. However, interspecific variation in values of $\beta_{\mathrm{NB}, \mathrm{NPi}}$ and $\mathrm{CaCO}_{3}$ tissue buffers does not apparently contribute to between-species differences in freshwater resistance.

Acknowledgements Inna M. Sokolova is grateful to the Otto Kinne Foundation for granting an OKF Fellowship which served for partial financial support of her studies in 1996 and to the AlfredWegener Institute for Polar and Marine Research (Bremerhaven, Germany) for supporting her work as a guest scientist in 19961998. Field work was in part financed by the Russian Foundation of Basic Research (grant N 98-04-49977 to IS). We are greatly indebted to Dr. Angela Sommer, Mr. Timo Hirse and Mr. Boris Klein for considerable help during experimental work. All experiments complied with the current laws of the countries (Russia and Germany) where they were performed. Alfred-Wegener-Institute publication no.1734.

\section{References}

Akberali HB, Mariott KRM, Trueman ER (1977) Calcium utilisation during anaerobiosis induced by osmotic shock in a bivalve mollusc. Nature (Lond) 266: 852-853

Babkov AI, Lukanin VV (1985) Spring changes of salinity and temperature in surface levels of the White Sea and their influence on distribution of organisms inhabiting intertidal and upper subtidal zones. In: Skarlato OA (ed) Biocenoses of Chupa Inlet and their seasonal dynamics (in Russian). Nauka, Leningrad 31: 94-98

Berger VJ (1986) Adaptations of marine molluscs to changes of environmental salinity (in Russian). Nauka, Leningrad

Brough CN, White KN (1990) Localization of metals in the gastropod Littorina saxatilis (Prosobranchia: Littorinoidea) from a polluted site. Acta Zool 71: 77-88

Byrne RA, McMahon BR (1991) Acid-base and ionic regulation, during and following emersion, in the freshwater bivalve, $\mathrm{An}$ odonta grandis simpsoniana (Bivalvia: Unionidae). Biol Bull 181: 289-297

Collip JB (1921) A further study of the respiratory processes in Mya arenaria and other marine mollusca. J Biol Chem 49: 297-310

Davies MS, Hutchinson SJ (1995) Crystalline calcium in littorinid mucus trails. Hydrobiologia 309: 117-121

Doumen C, Ellington WR (1992) Intracellular free magnesium in the muscle of an osmoconforming marine invertebrate: measurement and effect of metabolic and acid-base perturbations. J Exp Zool 261: 394-405

Dugal LP (1939) The use of calcareous shell to buffer the product of anaerobic glycolysis in Venus mercenaria. J Cell Comp Physiol 13: 235-251

Eberlee JC, Storey KB (1984) Buffering capacities of the tissues of marine molluscs. Physiol Zool 57: 567-572

Ellington WR (1993) Studies of intracellular $\mathrm{pH}$ regulation in cardiac myocytes from the marine bivalve mollusc, Mercenaria campechiensis. Biol Bull 184: 209-215

Frederich M, Sartoris FJ, Arntz WE, Pörtner HO (2000) Haemolymph magnesium regulation in decapod crustaceans: physiological correlates and ecological consequences in polar areas. J Exp Biol (in press)

Hand SC, Hardewig I (1996) Downregulation of cellular metabolism during environmental stress: mechanisms and implications. Annu Rev Physiol 58: 539-563

Hardewig I, Addink ADF, Grieshaber MK, Pörtner HO, Thillart $G$ van den (1991) Metabolic rates at different oxygen levels determined by direct and indirect calorimetry in the oxyconformer Sipunculus nudus. J Exp Biol 157: 143-160

Heisler N (1986) Buffering and transmembrane ion transfer processes. In: Heisler $\mathrm{N}$ (ed) Acid-base regulation in animals. Elsvier, Amsterdam, pp 3-47

Heisler N, Piiper J (1971) The buffer value of rat diaphragm muscle tissue determined by $\mathrm{PCO}_{2}$ equilibration of homogenates. Respir Physiol 12: 169-178 
Juretschke HP, Kamp G (1990) Influence of intracellular pH on reduction of energy metabolism during hypoxia in the lugworm Arenicola marina. J Exp Zool 256: 255-263

Kamp G (1993) Intracellular reactions controlling environmental anaerobiosis in the marine annelid Arenicola marina, a fresh look at old pathways. In: Hochachka PW, Lutz PL, Sick T, Rosental M, Thillart G van den (eds) Surviving hypoxia: mechanisms of control and adaptation. CRC Press, Boca Raton, Fla., pp 5-17

Kinne O (1964) Non-genetic adaptation to temperature and salinity. Helgol Wiss Meeresunters 9: 433-458

Kinne O (1971) Salinity. Animals. Invertebrates. In: Kinne O (ed) Marine ecology 1, part 2. Wiley, London, pp 821-996

Mason AZ, Simkiss K, Ryan KP (1984) The ultrastructural localization of metals in specimens of Littorina littorea collected from clean and polluted sites. J Mar Biol Assoc UK 64: 699-720

Mikhailova OY, Berger VJ, Kovaleva NM, Lavrova EA, Natochin YV, Khlebovich VV (1979) Electrolyte composition of muscles of marine molluscs during damage and reparation of the cells (in Russian). Cytologia 21: 579-585

Pörtner HO (1982) Biochemische und physiologische Anpassungen an das Leben im marinen Sediment: Untersuchungen am Spritzwurm Sipunculus nudus L. Dissertation, Universität Düsseldorf

Pörtner HO (1987a) Contributions of anaerobic metabolism to $\mathrm{pH}$ regulation in animal tissues: theory. J Exp Biol 131: 69-87

Pörtner HO (1987b) Anaerobic metabolism and changes in acidbase status: quantitative interrelationships and $\mathrm{pH}$ regulation in the marine worm Sipunculus nudus. J Exp Biol 131: 89-105

Pörtner HO (1990) Determination of intracellular buffer values after metabolic inhibition by fluoride and nitrilotriacetic acid. Respir Physiol 81: 275-288

Pörtner HO (1993) Multicompartmental analyses of acid-base and metabolic homeostasis during anaerobiosis: invertebrate and lower vertebrate examples. In: Hochachka PW, Lutz PL, Sick $\mathrm{T}$, Rosental M, Thillart G van den (eds) Surviving hypoxia: mechanisms of control and adaptation. CRC Press, Boca Raton, Fla., pp 139-156
Pörtner HO, Webber DM, Boutilier RG, O'Dor RK (1991a) Acidbase regulation in exercising squid (Illex illecebrosus, Loligo pealei). Am J Physiol 261: R239-R246

Pörtner HO, Andersen NA, Heisler N (1991b) Proton-equivalent ion transfer in Sipunculus nudus as a function of ambient oxygen tension: relationship with energy metabolism J Exp Biol 156: 21-39

Pörtner HO, Finke E, Lee PG (1996) Metabolic and energy correlates of intracellular $\mathrm{pH}$ in progressive fatigue of squid (L. brevis) mantle muscle. Am J Physiol 271: R1404-R1414

Schmidt H, Kamp G (1996) The Pasteur effect in facultative anaerobic Metazoa. Experientia 52: 440-448

Simkiss K, Mason AZ (1983) Metal ions: metabolic and toxic effects. In: Hochachka PW (ed) The Mollusca, vol 2. Academic Press, New York, pp 101-164

Sokal RR, Rohlf FJ (1995) Biometrics. Freeman, New York

Sokolova IM, Bock C, Pörtner HO (2000) Resistance to fresh water exposure in White Sea Littorina spp. I: Anaerobic metabolism and energetics. J Comp Physiol B 170: 91-103

Sommer A, Pörtner HO (2000) Exposure of Arenicola marina (L.) to extreme temperatures: adaptive flexibility of a boreal and a subpolar population. Mar Ecol Prog Ser (in press)

Thillart G van den, Waarde A van (1996) Nuclear magnetic resonance spectroscopy of living systems: applications in comparative physiology. Physiol Rev 76: 799-837

Van Dijk PLM, Hardewig I, Pörtner HO (1997) Temperaturedependent shift of $\mathrm{pHi}$ in fish white muscle: contributions of passive and active processes. Am J Physiol 272: R84-R89

Weich RG, Lundberg P, Vogel HJ, Jensen PE (1989) ${ }^{31}$ P-NMR studies of cell-wall-associated calcium phosphates in Uva lactuca. Plant Physiol 90: 230-236

Wiseman RW, Ellington WR (1989) Intracellular buffering in molluscan muscle: superfused muscle versus homogenates. Physiol Zool 62: 541-558

Zange J, Grieshaber MK, Jans AWH (1990) The regulation of intracellular $\mathrm{pH}$ estimated by ${ }^{31} \mathrm{P}-\mathrm{NMR}$ spectroscopy in the anterior byssus retractor muscle of Mytilus edulis L. J Exp Biol 150: $95-109$ 